QUAESTIONES GEOGRAPHICAE 32(2) • 2013

\title{
DWELLING OR LIVING IN A BLOCK OF FLATS. TOWARDS THE POLISH GEOGRAPHY OF HOME
}

\author{
EWA KLIMA \\ Department of Spatial Economy and Spatial Planning, University of Łódź, Poland
}

Manuscript received: August 5, 2012

Revised version: April 24, 2013

\begin{abstract}
KuIma E., 2013. Dwelling or living in a block of flats. Towards the Polish geography of home. Quaestiones Geographicae 32(2), Bogucki Wydawnictwo Naukowe, Poznań, pp. 81-90. DOI 10.2478/quageo-2013-0015, ISSN 0137-477X.
\end{abstract}

\begin{abstract}
AвSTRACt. This article consists of two parts. The first includes a review of Polish and mainly English-language publications in geography related to the theme of home and the flat. The second part presents the results of a study of 'homes in a block of flats'. It is primarily an attempt to identify opportunities that studying homes offers the contemporary cultural geographer. One of the aims is to pinpoint differences between the Polish and English output in this field, and to prove that such studies in our country are justified. The results clearly indicate the universal character of the notion of home and help to lift the spell of a hostile space off a block of flats. In more general categories related to the geographical understanding of space, it should be added that, as respondents indicate, this is a space which is neither homogeneous nor monotonous.
\end{abstract}

KEY wORDs: block of flats, geography of home, living, dwelling

Ewa Klima, Department of Spatial Economy and Spatial Planning, University of Łódź, ul. Kopcińskiego 31, 90-131 Łódź, Poland; e-mail:evaklima@uni.lodz.pl

\section{Introduction}

The article consists of two parts. The first includes a review of Polish and mainly English-language publications in geography related to the theme of home and the flat. The second presents the results of a study of 'homes in a block of flats'. It is primarily an attempt to identify opportunities that studying homes offers the contemporary cultural geographer. One of the aims is to pinpoint differences between the Polish and English output in this field, and to prove that such studies in our country are justified. The diversity of theoretical approaches enables the researcher to formulate many new problems.

The second part is an example of a study of home performed at the intersection of social and cultural geography. The object of the study was a special type of home - a block of flats. This form of housing is not the most desired form of a living place in Poland. The panelak (a large-panel building) is commonly associated with poor execution and design as well as strictly limited and highly uniform space. Today, more and more people consider living in a block of flats as a transitional solution, before moving to 'something better'. Those are mainly young people who inherited 
their first dwelling from, e.g., their grandparents. There are, however, a growing number of people who give up a lovely house with a small garden in the suburbs and long inconvenient commuting for a block apartment in the city.

The assumption of this research was that 'a home' was a notion describing relations between a human being and the place and people. Those relations are very intimate and personal in character. Dwelling is a process of building one's own identity, locating oneself in time and space. It could be expected that the process would satisfy one of the basic human needs: the need for security. The social context of home is defined by co-dwellers, usually the closest family and neighbours. In the case of a block of flats, home space is the flat itself (private space), shared or not with other people (in ideal conditions, those closest to a person), and its surroundings - all the areas located between the flat's door and the entrance to the building (quasi-public space) and the closest surroundings of the block of flats (public space, e.g. a car park, a children's playground, the entrance to the staircase). The distance in all those areas can be measured using the own/alien category. In the social dimension, a home in a block of flats is a space where we know people occupying it (we know, e.g., their names, at least some of them). Each of the three areas has its own structure. This also applies to a flat. Its space, though of a micro-scale, may be graded by its inhabitants.

The study utilised the qualitative method of collaborative photographs. Respondents were asked to take photographs on the theme of "My dwelling in a block of flats". The ambiguity of the term 'dwelling' was intentional to offer a chance of talking about dwelling as an activity or as an area within a space. The photographs taken were then discussed. Seven interviews were conducted. The study was carried out between 2011 and 2012 in Łódź.

\section{There's no place like home - home in Polish geographical research}

Even though it is one of the most important, or the most important, place for a human being, home as a notion has not received a comprehensive definition in Polish geography. This is prob- ably due to the dominance of the positivist (scientist) approach within the discipline. As a result, most studies concentrate on the types of urban housing where home appears first of all as an element of the structure or fabric of the city. Second$l y$, the theme of home is indirectly discussed by population geographers who analyse the household situation. The problem of living conditions, inhabitation conditions and dwelling conditions has generated a particularly rich body of literature. Among the authors who publish studies in this field one could mention Dzieciuchowicz (2002, 2011, 1972), Marcińczak (2009), Kaczmarek (1996), Suliborski (1976, 1972), Liszewski (1995), and Groeger $(2004 \mathrm{a}, \mathrm{b})^{1}$.

Dzieciuchowicz (2011:14) offers a definition of dwelling conditions. According to him, "Under this notion, people usually understand the technical and property-ownership status, the size, level of equipment and population of the housing stock viewed in relation to specific population needs." Traditionally, researchers identify internal and external dwelling conditions. The former, as the name suggests, refer to what is inside the flat: a quantified description of space (its square area, number of rooms, equipment, population, costs, etc.) External conditions refer to everything that is outside the flat. Thus, evaluation applies, e.g., to the residential area - its physical, social and service infrastructure. It is worth noting that there is also a notion of inhabitation conditions. Kaczmarek (1996) defines them as mutually related elements, such as: the flat, the building and the building's surroundings. Janiszewska et al. (2011) offer a similar approach towards the understanding of residential space within a block of flats writing about a close (private) internal space, a remote (quasi-public) internal space, and an external (public) space. The notion of 'public' means it can be accessed by people who are not the inhabitants of a given flat, e.g. neighbours or other people. Such an approach seems particularly apt as the analysis applies to multi-family housing. Discussions related to dwelling condi-

\footnotetext{
Polish geography has considerable achievements in the research on housing estates, neighbourhoods and city districts. Kotus (2005, 2007), Węcławowicz (2003, 2004, 2005) and Szafrańska (2010a, b, 2012) are among authors who have dealt with block-of-flats neighbourhoods.
} 
tions fit the broader research area of the standard of living and the quality of life, i.e. an objective (standard) and a subjective (quality) evaluation of need satisfaction.

Geography shares the basic notions related to dwelling and living (place and activity) with other disciplines, mainly architecture and urbanism. There are also references to terminology used in statistical research. The Central Statistical Office divides homes into: shelters for the homeless, shelters for mothers with minors and for pregnant women, malls, cultural centres, social aid centres, student houses, and department stores. However, home itself is not defined. There is, however, a definition of a dwelling. Thus, a dwelling is "a property consisting of one or more bedrooms and support rooms for continued occupation, built or redeveloped for residential needs; constructionally separated using fixed walls within a flat with an individual entrance from the staircase, corridor or common vestibule, or from the street, courtyard or garden"2 (Mieszkanie ...).

Polish geographers generally never approach the problem of inhabiting in the sense proposed by Heidegger (1977). In an essay entitled "Building, dwelling, thinking" he reflects on whether the sole existence of dwellings guarantees the 'situation' of inhabitation. Even though the text is a linguistic analysis of German vocabulary ('building', 'dwelling'), one can arrive at much more general conclusions on its basis. His view on space and place is only seemingly different from Tuan's (1977). According to Heidegger, "inhabitation is the basic outline of being which makes them mortal" (1977: 333). In order to inhabit, one must build and think. They do not possess any reflection upon the sense of dwelling as being. Tuan also argues that this does not entail a lack of knowledge of the significance of home. His discussion regarding intimate spaces can be translated onto Heidegger's discussion of being. The geographical research which relies on the accomplishments of the Polish humanities can only be limited to the question of the degree of satisfaction in dwelling, without any reflection on one's own 'being'.

2 On the basis of the Residential Property Act of 24 June 1994, Law Gazette of 2000 No. 80, item 903, amended.

\section{Home is the father's kingdom, the children's paradise, the mother's world - experience of English- language geography}

Although the notion of 'home' does not feature prominently in Polish geography, it has found a place in the seminal International Encyclopaedia of Human Geography. Its authors define home as "a material and an affective space, real or imagined, that is formative of personal and national identity, shaped by everyday practices, lived experiences, social relations, memories, and emotions" (Peil 2009: 5/180). It is then seen as a material phenomenon, as in Poland, and as an imaginative one. In the latter case it is strongly rooted in humanistic tradition and connected with the notion of topophilia (cf. Tuan 2004).

Apart from social geography with its humanities' paradigm, more interesting opinions and interpretations of home are offered by the feminist paradigm and radical geography. At this point, one must refer to Sibley (1995) and his Geographies of exclusion. He argues that geographers' interests usually focus on public space and are limited to what can be mapped. He further claims that home can be a place contaminated by the presence of people, activities or objects which induce a feeling of discomfort and which consolidate exclusion. He points out that regardless of this, people more often talk about "the house of heaven" than "the house of conflict", neglecting home as a locus of power relations in human geography. In this idealistic approach, space and objects form a whole similar to a gestalt, i.e. "a sense of organized whole which is greater than the sum of its parts, for the people who live with them, a gestalt secures a sense of individuality". But this is "too cosy" (Sibley 1995: 94). Home is not a sense of security or, as Heidegger wrote, cover and freedom. Home is also a context for violence, child abuse, depression, etc., and the routine use of space can provoke tensions and conflicts. Thus, reference to the paradigm of radical geography necessitates a transition to territorial micro-structures and severance with the positive symbolism of domestic space. Moreover, it requires a new look into the family. It can no longer be treated 
only in terms of a 'statistically' existing household the main goal of which is reproduction.

Home also belongs to the area of interest of feminist geography. It is one of the main structures exemplifying genderisation of space since femininity means the inside (the private) and masculinity - the outside (the public). After Valentine (2001), one can conclude that it is again a matrix of social relations and not just, e.g., an architectural issue. Yet, she stresses the weaknesses of the feminist approach ${ }^{3}$ of the 1970s and '80s, according to which the physical form of housing could literally be read as a map of the social structures and values which had produced it. She accuses its proponents of simplifications (the misconception that the built environment is a simple metaphor of the society that has produced it) and environmental determinism where women become victims of space. Changes in studying home have been forced by changes in social and economic life: paid women's work outside home and return of work (men's and women's) to home (cf. Massey 1998).

Valentine (2001) also emphasises the need for an intersecting approach. This proposal can be extended to other problems, not only those related with home. It seems that, even if not under this (feminist) paradigm, the author offers us a chance to understand home in terms of 'thirdspace', as initially proposes by Lefebvre (1991), Soja (1996) and Smith (1999). One can note an evolution of the view and study of home within the feminist framework.

Home, within various paradigms, is a subject of study of social and cultural geographers. The former highlight the meanings of home once more. Somerville (1992) summarises them as follows:

1. shelter - not only protection from the weather outside, but also a place of physical security;

2. hearth - a place to relax and to be comfortable ("at home") and from which to offer welcoming hospitality;

3. heart - emotional security, with the home providing a site of love and affection;

4. roots - a place in which to belong and which can be an expression of our identity;

A classic example of the second phase of feminism and The Second Sex by Simone de Beauvoir.
5. privacy - a legal and socio-cultural haven in which questions of "who enters" and "what are acceptable practices" can be regulated;

6. abode - a place to stay and to sleep; and

7. paradise - an idealised expression of the emotional pleasures of belonging, being safe, and feeling secure (after Warf 2006: 225).

Apart from meanings, social geographers analyse the experience of home. Home becomes a place of work, violence, resistance, negation and contestation. In 2005, a review of works in this field was published by Blunt in Progress in Human Geography. She starts with a definition of culture. After Anderson et al. (2003), she outlines its five scopes: culture as the distribution of things, culture as a way of life, culture as meaning, culture as doing, and culture as power (Blunt 2005: 506). She points to two approaches: phenomenological (human experience of a place) and contemporary, treating 'dwelling' as 'inhuman' thinking about space. She defines home (2005: 506) considering the human dimension: "The home is a material and an affective space, shaped by everyday practices, experiences, social relations, memories and emotions. [...] The meanings and lived experiences of home are diverse: 'As a space of belonging and alienation, intimacy and violence, desire and fear, the home is invested with meanings, emotions, experiences and relationships that lie at the heart of human life' (Blunt, Varley 2004: 3)".

Blunt organises the theme of home present in cultural geography by three main fields of study: residence, dwelling, and cohabitation. Residence refers to the architecture of houses and flats, their spatial organisation (specific sections of home), and material artefacts existing in the space. The home space itself is sometimes expanded to include, e.g., a garden or courtyard (cf. Bryden 2004). Researchers also analyse visual art and culture (cf. Painter 2002, Rose 2003). An analysis of family photographs offers a chance to establish relations with the past. It is also a spatial transfer, just as in the case of homes and migrants' photographs (Tolia-Kelly 2004).

Dwelling is the lived experiences, social relations and emotional significance of domestic life. This refers to both, a positive and a negative reception of home. There appear problems of 
exclusion, violence and homelessness. This also means entering the intimate zone: identity, affinity, which in post-colonial geographies is associated with transnationality and migration as well as their political aspects.

Cohabitation is understood by Blunt as "the domestic entanglements of nature and culture" (2005: 506). The author explains that those are philosophical and ethical reflections on the domestication and cohabitation of humans and non-humans within the home and garden space.

In 2006 Blunt and Dowling published their important book, Home. They presented there the term "critical geographies of home". It employs three overleaping elements. The first, "home as simultaneously material and imaginative", is a vision of home not only as a physical space but also as an imaginative place of feelings and belonging. The second, "the nexus between home, power and identity", means connections between home as a locus of personality and 'social' identity (according to age, gender, ethnicity, etc.). The last element, "home as multi-scalar", might be described as a catalyst for or transition between personal, public and political worlds. As Brickell (2012: 227) concludes, Blunt and Dowling "propose a 'critical geography of home' which moves beyond a binary of exclusionary or idealized space to show the ambiguity of this 'spatialized' and 'politicized' space". She also calls for a 'new' critical geography of home and suggests that 'doing' and 'mapping' have to meet and be treated as complementary attitudes. She argues: "'mapping' remains an important prerequisite for 'doing' if interventions or otherwise are to be appropriately tailored and actioned, especially when dealing with the intricacies and politics of domestic life. (...) the mounting professional onus on academics to directly 'get out there' and 'do' something (Castree, 1999) to challenge negative expressions of home needs to be balanced against their bringing to light of affected people's own forays into the politicization and publicization of domestic issues" (2012: 238).

\section{Blocked and locked ${ }^{4}$ - in search of a new perspective for Polish research into blocks of flats}

Since the mid-20th century, there has existed an unequivocally pejorative notion of 'blokowisko' (a large body of blocks of flats). The poet and writer Miron Białoszewski, upon moving from downtown Warsaw to its block-of-flats suburb Ursynów, wrote that he had landed in Chamowo (Roughville) (1978). However, one must remember that residential districts and blocks of flats stem from the idealist principles of the 19th-century social and urban development concepts (utopian cities) ${ }^{5}$, directly related to the Athens Charter signed in 19336. It was a document of the 4th International Congress of Modern Architecture (Congrès International d'Architecture Moderne-CIAM). Its authors proposed functional changes of cities. The main proposals were to 'air' them and make residential districts privileged, so as to make them de-congested and full of greenery. They also proposed the introduction of loosely distributed apartment towers (Syrkus 1976). Formally, many contractors and urban designers drew upon neoplasticism ${ }^{7}$, the main representative of which was P. Mondrian". The new trend in architecture was called 'the international style'. Its main features included the use of reinforced concrete, emphasis on the functionality of buildings, modularity (use of modules), and the ability to produce prefabricated elements. The most famous people of that period were W. Gropius, A. Meyer, A. Reinhard and L. van der Rohe, but most of all Le Corbusier. This Swiss architect is considered the father of the

4 After M. Białoszewski (1978) - “Zblokowani - zklocowani".

5 One might quote here, e.g., Ch. Fourier's phalanstere, i.e. the idea to build self-sufficient communities (ca. 1,600 people) in buildings distributed in a square layout.

6 In 2003, the European Council of Town Planners published a document entitled "The New Charter of Athens. The ECTP vision for cities of the 21st century".

7 Neoplasticism is also called "Der Stijl", which is Dutch for "style". Probably the best known institution promoting it was the Bauhaus, a German art institute.

P. Mondrian, P. Klee, W. Kandinsky and K. Malewicz are considered the creators of abstract painting (Estreicher 1984). 
block-of-flats building industry. Unfortunately, Polish blocks of flats after the Second World War had very little in common with the initial artistic and architectural concepts. And very few social proposals survived. Blocks of flats became not only a synonym of ugliness, but also of atrophy of community life.

It seems that blocks of flats are a special type of houses. They entail a special space and a special lifestyle. However, the essence of home remains the same. Close and troublesome neighbours do not influence the domestication of space, though they surely influence one another's lives. A dwelling in a block of flats becomes for its inhabitants 'mine' or 'ours', and the highest point in their universe, almost always receiving the highest (positive) valuation.

"I respect my dwelling because it seems that this is the best place where a person lives, where a person relaxes, lives, so I will go somewhere, even if I go to my son, I don't like to spend there too much time because I think that my home is the best." (Respondent 1)

"My own place, my space. And it's just, well, a piece of residential space where you can feel good, right? [...] It's some kind of a sense of security that you come back to your place, that you have something that is yours. And that it's just something of yours, where you can feel at home regardless of all the inconveniences, such as the lack of intimacy." (R3)

Such opinions do not, however, mean there are no critical opinions. Yet, apparently, that which is bad is not located within the private zone.

"R: Do you like your dwelling?

A: I do.

A: Is it your first, long-awaited dwelling?

$\mathrm{R}$ : Yes, my first, long-awaited. You know how it is. It's like when you're building a house. You build your first house for your enemy, the second one for your friend, and only the third one for yourself. And this is my first dwelling, so...

A: What would you change?

R: The location." (R3)

The floorspace of the dwellings is not a problem - its insufficiency is.

"Generally, I associate dwelling in this block of flats with limited living space. It took me a long time to decide what to show and this finally seemed most appropriate and the resulting limited space, e.g. children sleeping in bunk beds because we cannot afford for both of them to have their own rooms." (R6)
The structure of the living space is usually created by nodal points - favourite or important places. Some respondents called what they had chosen "my favourite place at my home". One might suspect that such an axis mundi, a transition point, would be the table. However, no one took a photograph of one, and no one even mentioned a table in this sense. The focal points of the living space were leisure items - armchairs.

“A: And do you have your favourite space within your dwelling, your favourite place?

R: This armchair, this armchair.

A: Why?

R: Because it's close, for example, to the window and that's how I feel and yeah. When I sit in it, I can see everything around me." (R7)

Only one respondent showed us around his dwelling, presenting all the rooms. He started systematically - with the entry hall. At the same time, he quite specifically showed us what decided about its identity. He talked about it by describing the colours on the walls - the respondent is a historian.
"R: [...] the entrance is very important. I even tried to arrange it in such a way that it would not be clattered, so it would not be an obstacle when entering, which is not only for me but for all the inhabitants. So that there would be a clear and ac- cessible passage through the hallway. And I also tried to arrange it in a modest but tasteful, as I feel it, way.
[...] it's the beginning..., this is where you enter, exit. So basically it's a neck, bottleneck, if you will. A: So I understand that everything there is well thought-out and purposeful. For example the col- ours on the walls.
$\mathrm{R}$ : Well, the colour is Pompeian red, which is close to me, professionally ... but it is also a lively col- our, in a sense, not like some... A room without any source of light cannot have dark colours." (R5)

Home is placed within time structures. The fact that it is located in a block of flats does not change anything. Its dynamics is visible in the daily cycle. Its various parts are used with various intensity during the day and at night. There are places which 'switch owners' and completely alter their functions.

" $\mathrm{R}$ : In the first picture, there is our bedroom. That hanging thing, those two angels of harmony hang right in the middle above our bed. They have been hung there on purpose by my wife so that we would always live in peace, so to speak, right? So 
that even if we fall out, we could at least reconcile in bed. Because that's the way it sometimes is that people reconcile in bed, right? [...] And it's the worst situation, God forbid, to go to bed angry, then it's really bad...

[...] I don't really know how important a bed is for other families, but, in general, the bed is important for our kids as well because they use it during the day as a springboard and for other weird stuff and we have to calm them because they turn it into a real playground." (R2)

Home within a block of flats symbolically unites its inhabitants with their ancestors and with the past, giving them at the same time a foundation for their individual and family identity within a certain continuum. Its symbols are the furniture and paintings (photographs).

“ $R$ : In the second picture, that's the cupboard in the living room, you mean generally what is in the corner of the room, right? But generally, that cupboard and all that lies on it, as I was taking the photograph, I looked at it, it's such a homely spot - a museum is not a good word, yes, but it's like... First of all, the cupboard is important because it's our grandma's cupboard, saved from the turmoil, as I always say, because it was supposed to be destroyed, it was supposed to be thrown out. We decided that it would be a great loss and we restored it, right? So it stands here and serves us, it's also like a piece of history. Well, so you could say that it's a piece of the room with a history, right? Different, well, people, or places, or things, right? Because, as I'm saying, it's a historic cupboard of our grandma. There are our pictures, well, wedding photos, our family photos from various times. They are important at a given moment, significant, for my wife, for example, gifts that she has received, this is the most recent one, right? This box, yes, well this is something ... for precious things." (R2)

Home can also be 'adjusted' to the time structure which signifies the yearly cycle - the passage of seasons, summer to winter.

"I would like to show you my entire dwelling because it's beautiful, and I like some places in summer, and when it's cold I like other places. Because now, the most important is my dear little armchair. The kitchen is close, the TV is right in front. Yes, this is a winter-time place.

Because in summer, my most favourite place is on the balcony. I have plants, I love to sit there, a flower here, a flower there, here's my armchair and I look down at what people are doing there, but, generally, I love sitting on the balcony because this is my link with Łódź." (R4)
In this statement one might find some interesting elements: the balcony (a window for others, for obvious reasons) as a link with the outside.

"If there is a balcony, then it's so nice at home. You can dry something, put something there. Well, it's a third room, that's how I see it. When I sit there the whole summer, I think I have three rooms and a kitchen, because in my small rooms ... I sit around, the armchair is always there, [...] I sit there all the time. In the morning and in the afternoon. Whether it's sunny or not. I used to do a bit of sunbathing, but then I could not sunbathe any more because when you get old and sick you cannot sunbathe any more, but I still sit a lot on my balcony. When it's hot, I sleep till two in the afternoon there." (R1)

Another element is plants - non-human nature. For one of the respondents flowers have become a focal point of his home.

“R: My beautiful araucaria [...], I wanted it as an element of nature. My favourite plant is araucaria. According to people of the East, coniferous plants are preferred by men, by warriors, with all relevant connotations ..., so I have an araucaria, as well as other coniferous plants, Chinese junipers, which aren't here. Araucaria is particularly close to me as it is a demanding plant, well, which requires, first of all, one person looking after it, secondly, a caring person, and it needs some comfort. It shouldn't stand near an opened window, it shouldn't be moved. The bottom line is that you have to take good care of it.

A: Like a demanding woman ...

R: Well, yes, but there's no comparing it with my wife, who is very ... feminine.

A: Araucaria is probably less expensive?

$\mathrm{R}$ : Well, yes, my wife is always on-line and buys the kid some necessary and unnecessary things, and some necessary things for herself, and even for me." (R5)

It is often said that a city is a place where a person can look from the windows of one home into the windows of another. For a large number of people, blocks of flats are a symbol of such looking into the neighbours' windows. It turns out, however, that the mixing of the public with the private usually occurs within the audio zone. In short, neighbours are usually heard rather than seen.

"It works both ways. I can hear them, they can hear me. I think that, considering my lifestyle, they can seldom hear me. But when I come back home and I would like to spend the evening in peace and quiet, and I can hear through one wall a kid 
shouting till midnight and through another wall a young married couple where he can play video games or some shooters all night long, then, well, this isn't the best aspect of my living in a block of flats." (R3)

Whether people know their neighbours depends on their age, how they have lived there and on which storey they live. An older respondent, who had lived in the same place for 40 years, was able to list from memory not only their names, but even the marital status of her neighbours: "We have twenty inhabitants in this block of flats. You know, there are eight widows, one widower and one older bachelor. This gives us ten singles, the rest are couples, and there are three families of three." A young inhabitant from the ground floor said something completely opposite: "I don't know my neighbours' names. I mean, I know the neighbours who live above me, and those on the fifth floor, but if you asked me to tell them one from another, I could do it by their dogs and cars, who drives what and who walks which dog." (R6)

It is interesting that no one took any photographs of the staircase, attic or elevator, nor did anyone take a photograph of their neighbour. Some people were not even aware there were such amenities as a laundry room or a drying room. Cellars were rarely visited. No one mentioned such areas spontaneously. Comments would appear after extending the interview. An inhabitant of the first floor offered some interesting comments on the elevator and his neighbours.

“[...] I have noticed a difference, yes, because now that I live on the first floor and when I used to live with my mum on the ninth floor, the difference is that when I lived on ... , basically, the lower you live, the fewer neighbours you have whom you know and, basically, you are less aware of who lives in your block of flats, basically.

[...] when I used to live on the ninth floor and when I used to take the elevator, I would always meet someone so I knew who entered the elevator on which floor, on which floor he was, yes, so I had a better overview of who lived in the flats in my staircase. I knew that this was someone from my staircase. But now that I live on the first floor, I know who lives on the ground floor, and maybe who lives one, two floors above me, but I have no idea of who lives on the ninth, eighth, seventh floor. I don't, I don't know those people, I don't. I only remember some of them, because when we used to have a dog, I would walk it and there were other people walking their dogs, so there was something we had in common, yes, something clicked and ... there must be some common element. The common element when I used to live on the ninth floor was taking the elevator, right? There was a neighbour who would come into the elevator and we would use it together, and would say hello, right? Sometimes a few more words." (R2)

It turned out that the title "My dwelling in a block of flats" was understood literally and it was limited to the living space. The quasi-public and public space was presented only as an area for meeting neighbours. This does not mean that anything outside home is identical or, which would be even worse, not important. A homeless person, a very special user of the block space, noticed all the details.

"Blocks of flats differ in terms of construction, because there are those where everything is in front, in front of flats and you can see everything through the peephole, right. Yeah. But there are others which have, well, recesses, that you don't see anything there and you can sit there in peace, but you have to remember not to make too much noise." (R8)

\section{Conclusion}

The first aim of the article was to present differences between the outputs of Polish and English-language geography. It is mainly a result of Polish geography limiting studies of home only to the positivist approach. The word 'home' itself is virtually absent from any studies. One might only find some indirect references when dealing with important or significant places. At the same time, there are many publications related to living conditions and dwelling conditions. Regardless of whether the authors refer to the output of economic or social geography, they use a quantitative method of research.

English studies are much more diverse. More than one paradigm is significant. Home as an object of study is mostly explored by feminist geographers dealing with gender issues. The theme is also tackled by cultural geographers, whose publications will include references to any given element of culture: values, norms or material objects. Home is understood not only as a space for 
living, but also as a space for social relations. It is what gives identity and supports identity. A special example is the research on immigrant homes performed within the paradigm of post-colonial geography. In human geography, researchers clearly focus on individuals.

The second aim was to present the results of an empirical study conducted in a block of flats in Łódź. The researchers used the assumptions of cultural geography. The results clearly indicate the universal character of the notion of home and help lift the spell of a hostile space off blocks of flats. In more general terms related to the geographical understanding of space, it should be added that, as the respondents indicated, this is a space which is neither homogeneous nor monotonous. It undergoes constant material and conceptual transformations. Finally, home does not only consist of walls, media, people, furniture, plants and views, but also implies the process of living.

\section{References}

Anderson K., Domosh M., Pile S. \& Thrift N. (eds), 2003. Handbook of cultural geography. Sage, London.

BiaŁoszewski M., 1978. Odczepić się. Czytelnik, Warszawa.

BLunT A., 2005. Cultural geography: Cultural geographies of home. Progress in Human Geography, 29(4): 505-515 .

Blunt A. \& Dowling R., 2006. Home. Routledge, Abingdon.

Blunt A. \& VARLEY A., 2004. Geographies of home: Introduction. Cultural Geographies, 11(1): 3-6.

BRICKELL K., 2012. 'Mapping' and 'doing' critical geographies of home. Progress in Human Geography, 36(2): 225-244.

BRYDEN I., 2004. 'There is no outer without inner space': Constructing the haveli as home. Cultural Geographies, 11(1): 26-41.

CAstree N., 1999. 'Out there'? 'In here'? Domesticating critical geography. Area, 31(1): 81-86.

DzIeciuchowicz J., 2002. Zasoby mieszkaniowe Łodzi: Rozwój, struktura przedmiotowa i przestrzenna (The housing stock of Łódź: Development, type and spatial structure). Łódź University Press, Łódź.

Dzieciuchowicz J., 2011. Środowisko mieszkaniowe wielkiego miasta. Przykład Łodzi (Housing environment of a big city: An example of Łódź). Łódź University Press, Łódź.

Dzieciuchowicz J., Stolarczyk B. \& Suliborski A., 1972. Warunki mieszkaniowe centrum Kielc w ujęciu przestrzennym (Housing conditions of the Kielce downtown in a spatial approach). Zeszyty Naukowe Uniwersytetu Łódzkiego, 49: 37-65.

Estreicher K., 1984. Historia sztuki w zarysie (The history of art: An outline). PWN, Warszawa.

GROEGER L., 2004a. Waloryzacja przestrzeni mieszkaniowej w opiniach klientów tódzkich biur obrotu nieruchomościami (Eva- luation of residential space in the opinions of clients of Łódź real-estate offices). Łódź University Press, Łódź.

Groeger L., 2004b. Standard otoczenia miejsca zamieszkania a zróżnicowanie preferencji mieszkańców Łodzi (Standard milieu of the place of residence and preferences of Łódź residents). In: Jażdżewska I. (ed.), Zróżnicowanie warunków życia ludności w mieście. XVII Konwersatorium Wiedzy o Mieście. Łódź University Press, Łódź: 189-198.

Heidegger M., 1977. Budować, mieszkać, myśleć: eseje wybrane (To build, inhabit, think: Selected essays). Czytelnik, Warszawa.

JANISZEWSKa A., Klima E. \& RochmińsKa A., 2011. Jakość życia na łódzkich osiedlach (Quality of life on Łódź housing estates). In: Dzieciuchowicz J. (ed.), Wspótczesne przemiany środowiska mieszkaniowego - wybrane problemy. Łódź University Press, Łódź: 145-180.

KaCZMAREK S., 1996. Struktura przestrzenna warunków zamieszkania w Łodzi (Spatial structure of housing conditions in Łódź). Łódzkie Towarzystwo Naukowe, Łódź.

Knox P. \& Pinch S., 2006. Urban social geography. Pearson Prentice Hall, Harlow.

Kotus J., 2005. Społeczne dylematy w przestrzeni miejskiej (Social dilemmas in an urban space). Bogucki Wydawnictwo Naukowe, Poznań.

Kotus J., 2007. Natura wielkomiejskich sąsiedztw: analiza subsasiedzkich i sasiedzkich terytorialnych podsystemów społecznych w Poznaniu (Nature of big-city neighbourhoods: An analysis of sub-neighbourhood and neighbourhood territorial social subsystems in Poznań). Adam Mickiewicz University Press, Poznań.

Lefebvre H., 1991. The production of space. Blackwell, Oxford.

LisZEWSKI S., 1995. Zróżnicowanie przestrzenne poziomu i jakości życia $w$ aglomeracjach miejskich (Spatial differences in the level and quality of life in urban agglomerations). Acta Universitatis Lodziensis, Folia Geographica Socio-Oeconomica, 20: 207-217.

MARCIŃCZAK S., 2009. Przemiany struktury społeczno-przestrzennej Łodzi w latach 1988-2005 (Changes in the socio-spatial structure of Łódź over the years 1988-2005). Łódź University Press, Łódź.

MAsSEY D., 1998. Blurring the binaries? High tech in Cambridge. In: Ainley R. (ed.), New frontiers of space, bodies and gender. Routledge, London: 157-175.

Mieszkanie, Pojęcie stosowane w badaniach statystycznych statystyki publicznej (Dwelling: the notion employed in public statistics surveys). GUS, http://www.stat.gov.pl/gus/ definicje_PLK_HTML.htm?id=POJ-353.htm.

Nowa Karta Ateńska (New Charter of Athens), 2003. Towarzystwo Urbanistów Polskich. Available at: http://www. zabytki-tonz.pl/pliki/karta\%20atenska\%202003_pl.pdf.

PAinTer C. (ed.), 2002. Contemporary art and the home. Berg, Oxford.

Peil T., 2009. Home. In: International encyclopedia of human geography. Elsevier, Amsterdam: 180-184.

Rose G., 2003. Domestic spacings and family photography: a case study. Transactions of the Institute of British Geographers, 28: 5-18.

SibLEY D., 1995. Geographies of exclusion: Society and difference in the West. Routledge, New York.

Sмiтн S., 1999. Society - space. In: Cloke P., Crang P. \& Goodwin M. (eds), Introducing human geography. Arnold, London: 18-34.

SoJA E., 1996. Thirdspace. Blackwell, Oxford. 
SOMERVILLE P., 1992. Homelessness and the meaning of home: Rooflessness or rootlessness. International Journal of Urban and Regional Research, 16(4): 529-539.

SulibORSKI A., 1976. Środowisko mieszkaniowe miasta jako przedmiot badań geografii osadnictwa (Housing environment of a city as an object of study of settlement geography). Acta Universitatis Lodziensis, Nauki Matematyczno-Przyrodnicze, 2(7): 123-135.

Syrkus H., 1976. Ku idei osiedla społecznego (Towards the idea of a social settlement). PWN, Warszawa.

SZAFrAŃSKA E., 2010a. Wielkie zespoły mieszkaniowe - ich przemiany i miejsce w strukturze społeczno-przestrzennej współczesnego miasta. Przykład Łodzi (Large housing complexes, their transformation and place in the socio-spatial structure of a modern city: The case of Łódź). Studia Miejskie, 2: 193-206.

SZAFRAŃSKA E., 2010b. Wielkie osiedla mieszkaniowe w okresie transformacji - próba diagnozy i kierunki przemian na przykładzie Łodzi (Large housing estates in the transformation period: A diagnosis and tendencies of change. The case of Łódź). In: Jażdżewska I. (ed.), Osiedla blokowe w strukturze przestrzennej miast. Łódź University Press, Łódź: 219-236.

SZAFRAŃSKA E., 2012. Przemiany struktury społecznej, przestrzennej i funkcjonalnej wielkich osiedli mieszkaniowych na przykładzie osiedla Widzew-Wschód w Łodzi
(Changes in the social, spatial and functional structures of large housing estates: An example of the Widzew-Wschód estate in Łódź). Space - Society - Economy, 11: 179-186.

Tolia-KelLy D., 2004. Materializing post-colonial geographies: Examining the textural landscapes of migration in the South Asian home. Geoforum, 35: 675-688.

TuAN Y.-F., 1977. Space and place: The perspective of experience. University of Minnesota Press, Minneapolis.

TuAn Y.-F., 2004. Home. In: Harrison S., Pile S. \& Thrift N. (eds), Patterned ground: Entanglements of nature and culture. Reaktion Books, London: 164-165.

Valentine G., 2001. Social geographies: Space and society. Prentice Hall, Harlow.

WARF B. (ed.), 2006. Encyclopedia of human geography. Sage, London.

WęCŁaWowicz G., 2003. Large housing estates in Poland: overview of developments and problems in Warsaw. Faculty of Geosciences, Utrecht University, Utrecht.

Węctawowicz G., 2004. Large housing estates in Poland: policies and practices. Faculty of Geosciences, Utrecht University, Utrecht.

WęCŁaWowicz G., 2005. Large housing estates in Warsaw, Poland: opinions of residents on recent developments. Faculty of Geosciences, Utrecht University, Utrecht. 